\title{
THE DECORATIVE DESIGN IN BRANCOVENIAN PAINTING (THE PAINTING DURING THE REIGN OF CONSTANTIN BRANCOVEANU)
}

\author{
Grecu Dorin \\ Senior Lecturer, Phd, University of Piteşti, Romania, dorin_grecuro@yahoo.com
}

\begin{abstract}
The Brancovenian style characterizes the art, the architecture and the plastic arts from Wallachia, during the reign of Constantin Brancoveanu (1688-1714). The Brancovenian art is a type of art that has an eclectic spirit. In the Moldavian architecture, it adds Gothic influences over the Romanian and Byzantine structures, at which it has been added Oriental and Reinaissance elements, especially Baroque ones. Out of this complex combination, it emerges a Romanian and unitary style, known as the Romanian Baroque.

In Brancovenian art, the decorative design or the ornament has a crucial importance, first of all, due to its journey to the easiest visible architectonic land, and, second of all, due to its enrichment and diversity.

The ornament is now adapted to the architectural space through the settlement of the fitomorphus decorations in the exterior painting, and, in the interior painting through filling empty spaces with combined friezes from vegetal elements.

A new direction in the evolution of the ornament is its shift from merely decorating architectural buildings to decorating the background of the paintings. Afterwards, the ornament is highly encountered on background objects, especially on thrones where holly persons were put and in the decoration of the clothes belonging to saints or founders (henefactor). During this period, the ornament has a crucial importance in painting. The space of the elements that, until recently, was filled only by the shaping light or colour, is now receiving decorations.

Thus, the clothes of the characters inspired from the paintings originating in Crete, are enriched by ornaments with vegetal elements, and influenced by the Western Baroque. By studying the plastic and stylistic analysis, we can observe the fact that the ornament has the role of decorating the background surfaces, phenomenon encountered in the tradition of Byzantine painting, and it is introduced in the pictural field, establishing a certain relationship with the inner pattern of the respective elements. Thus, Brancovenian painting manages to create a synthesis between East and West, becoming unique and imposing itself as a personal style of the Romanian-Byzantine painting to universal art.
\end{abstract}

Keywords: art, Brancovenian painting, ornament, decorative element

\section{INTRODUCTION}

In Wallachia, the end of the seventeenth century and the beginning of the eighteenth is dominated by the outstanding reign of Constantin Brancoveanu. This period is known to have had an intense constructive activity, encouraged by the long reign of this lord, by his fabulous wealth, and, especially, by his undoubted 
interest towards everything that meant life, splendor and luxury. The company responsible for civilian edifice has witnessed an evolution never seen before in the history of the country.

Renowned for his intelligence and culture, educated in the distinguished environment present at the royal courts of the Cantacuzinos, Constantin Brancoveanu was always receptive towards the cultural and artistic values and concepts. At his royal courts, in Bucharest and in Targoviste, he gathered the best craftsmen in the area, but also stone cutters and silver artists from Transilvania, painters from Greece, wood carvers from Dalmatia and even from Italy. Truly an endowed man, he possesses numerous foundations, estates and religious artefacts like altar screens, icons, silverware, embroideries, books, crosses and splendid attire. In what concerns the religious edifices, his most appraised foundation is Hurezi Monastery, where the building site has become an important school of art for the Brancovenian era. The reason why Hurezi School of Art is so important is that, at some point in the past, it welded together the creative forces in the area, thus giving birth to a community of artists.

With respect to the Phanariot Age, we should consider the fact that the foundations were not built only from the will of kings, but also from the will of important or less important boyars (landowners), of low status lords, of clergymen, both bishops and small ministers or monks. In comparison to the previous centuries, we can witness a growth in the building of churches by wealthy citizens (merchants, heads and bailiffs of guilds, craftsmen), this fact standing as a clear evidence for their social evolution due to the development of trade, of the number of practiced professions and the birth of the first manufactories.(Panaitescu, Simetria Edition, Bucharest, 2008, p.30).

The Brancovenian period has given us a great heritage. A great number of painters, wood carvers, miniaturists, sculptors and broiderers created truly magnificent masterpieces that wear their names. Among the greatest painters of the time, we can mention Constantinos and Parvu Mutu.

\section{GENERAL FEATURES OF THE BRANCOVENIAN PAINTING}

Plastic art is linked to the great, international and Post-Reinaissance styles - the Baroque and the Mannerism, without losing its traditional, formal and structural features. Also, the Greek culture and language infiltrated deep within Wallachia will spread ideas, concepts and artistic solutions both from the West and from the East. During the time of Vasile Lupu and Matei Basarab, in Moldavia and Wallachia, the artistic and cultural efflorescence has led to the birth of the so-called Brancovenian style. This style has welded together a great number of foreign elements with a solid and ancient tradition, thus giving birth to masterpieces of great value and originality.(Vasile Florea, Bucharest-Chisinau, 2007, p.217-218) As a new element, we can witness a certain tendency towards a narrative style, despite the monumental and representative structure of the paintings. This new tendency has been encountered for the first time in Moldavian painting, in Sucevita. (Florea, Bucharest, 1982, p.49)

The Brancovenian period has given us a great heritage. A great number of painters, wood carvers, miniaturists, sculptors and broiderers created truly magnificent masterpieces that wear their names. The decorative elements that can be found in wood carving are also present in painting. (https://ro.wikipedia.org/wiki/Stilul brâncovenesc) Among the greatest painters of the time, we can mention Constantinos and Parvu Mutu.

Parvu Mutu, born in Muscel, the painter of the Cantacuzinos, represents the national trend. He has practiced a more individual way of painting and owes his reputation to galleries of votive portraits and a number of selfportraits. In Bucharest, at the beginning of the eighteenth century, he has founded a school, where he taught the art of painting. (Teodora Voinescu, Bucharest, 1968, pp. 6,7)

Constantinos, born in Greece, educated in the distinguished environment of the Crete-Aton School where he has learnt a number of methods used in the Italian, Baroque painting, has work a long period in Wallachia, from the time of Serban Cantacuzino (FLOREA Vasile, Bucharest-Chişinău, 2007, pp. 260,261) He has been appointed headmaster of Hurezi School of Art and will grow to be a true leader for the artistic movement. The Greek influence is making itself present throughout the evolution of the Romanian icon, despite political shifts in this part of Europe regarding the positions of the state, Church and government.

The icons are remarkable, being endowed with great richness, standing as clear evidence of the taste for splendor and opulence shown by Constantin Brancoveanu. A feature of the Brancovenian icons is represented by the mobile, two-faced wakes and the interest in depicting certain episodes and moments surrounding the main scene. Another feature is the preference for certain iconographic motifs: Virgin Mary Reigning with the Infant in Her Lap - when painting Brancovenian icons, the throne is regarded as an element of props. This motif is dedicated to heavenly icons, which, together with the Hodighitria type, is more frequently encountered, underlining the importance of Virgin Mary. 
In the icons painted during this period, we can witness a certain interest towards the illustrative, the narrative, an accentuation of movement, a more open expression of gestures and physiognomies, treated with a more realistic spirit and the use on a large scale of the Baroque, vegetal ornament. Also, there is certain predilection in the abundant use of gold, not just for the background, but also for the decorations and attire. More discreet, at the beginning, these features reach their full potential during the reign of Constantin Brancoveanu. During the Brancovenian period, the painting of icons manages to impress the audience through its richness and sumptuousness. The typology of the characters receives specific features: the face is more prolonged, the big eyes are emphasized by the dark rings, the eyebrows are arced and elongated towards the temples, the lower lip is emphasized by a certain shadow. Apart from the art of depicting faces, great importance is also lain on the exquisite execution of the attire, represented through a vivid chromatics, with shades of red, blue and green, nicely harmonized with the golden, shining background, sometimes decorated with cut, vegetal motifs.

\section{THE ORNAMENT IN BRANCOVENIAN PAINTING}

The merit of the Brancovenian period is represented by the fact that is has succeeded in harmoniously adapting the exuberance of the setting at the shape of the decorated artifact. In every artistic masterpiece of the period, in wood and stone carving, embroideries and cloth, in painting and manuscripts, we can easily identify this decorative type, which will become an important feature of the Brancovenian style.

As part of the Brancovenian, decorative repertoire we can mention helianthus flowers (sunflower), peonies, vivid depictions of dahlias, shells, mascheronies, winged heads of angels, birds, fantastic creatures, dolphins, human faces and vases with flowers. The vegetal, figurative, floral and geometric ornaments are welded together with the creeping stern to form unitary structures, sometimes, leaving enough space for heraldic motifs, suggesting a certain sense of balance and order. At the end of the seventeenth century and the beginning of the eighteenth, the art and culture in Wallachia has witnessed a period of stability and blooming of the very first national trend, also known as the Brancovenian Style.

In Brancovenian painting, we can observe delicate, round-shaped ornaments filled with arabesques shaped like vegetal stalks, vines or plant strains(Fig.1) and also slightly geometrical ornaments that depict the same vegetal motifs intertwined with geometric motifs.(Fig. 2)

\subsection{The decoration of empty spaces encountered in paintings}

The ornament is now adapted to the architectural space by settling the fitomorphus decorations (fig.5) onto the exterior painting. In the interior painting, the ornament is used to fill in the empty spaces with vegetal motifs and delicately painted, tiny flowers. (FLOREA Vasile, Bucharest-Chişinău, 2007, pp. 260) Brancovenian decoration is filled with vegetal, geometric,antropomorphus, avimorphus and zoomorphus motifs used in asociation or separate. (Dobjanschi A., Georgescu.M., Daim Edition, Bucharest, 1998, p. 18) They emerge as ornamental structures between the registers that unfold in the architectural space, filling it both cromatically and compositionally, but with great care not to exceed the right and harmonious proportions. This type of decoration is not found only between registers and scenes, it also adapts perfectly to fill in the spaces that are hard to reach like the lintels of doors and windows and the backside of the arches found in Byzantine architecture. These are spaces where other types of compositions cannot be used because of their small sizes and because of the painter's will to diversify the image.

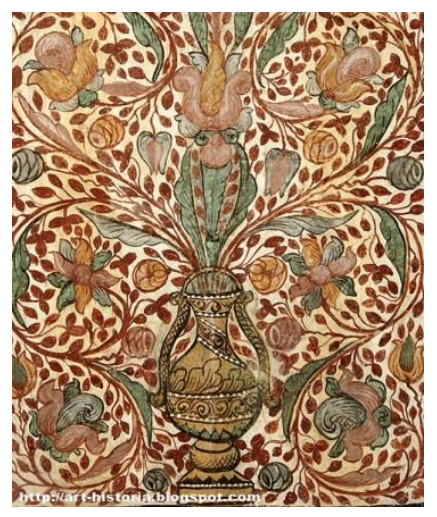



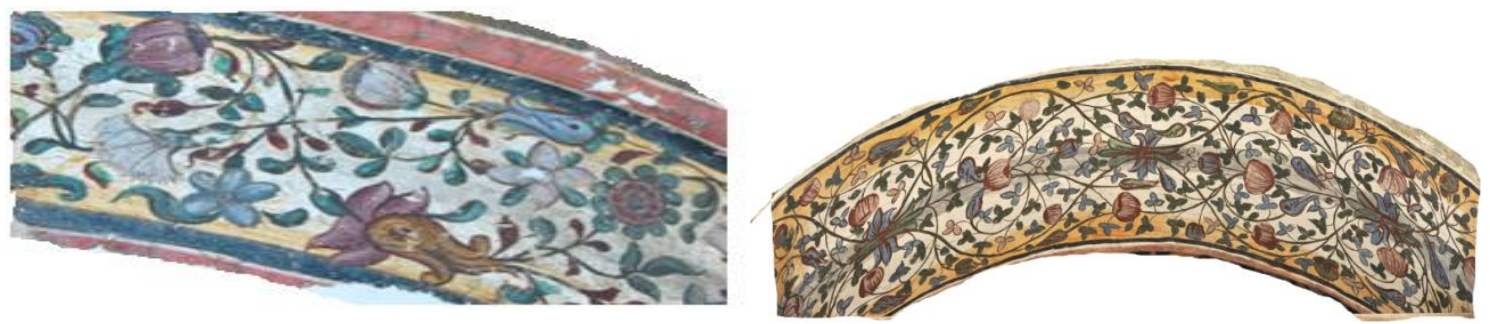

Fig. 1. Delicate, Brancovenian, floral ornaments the from empty spaces found at Hurezi Monastery
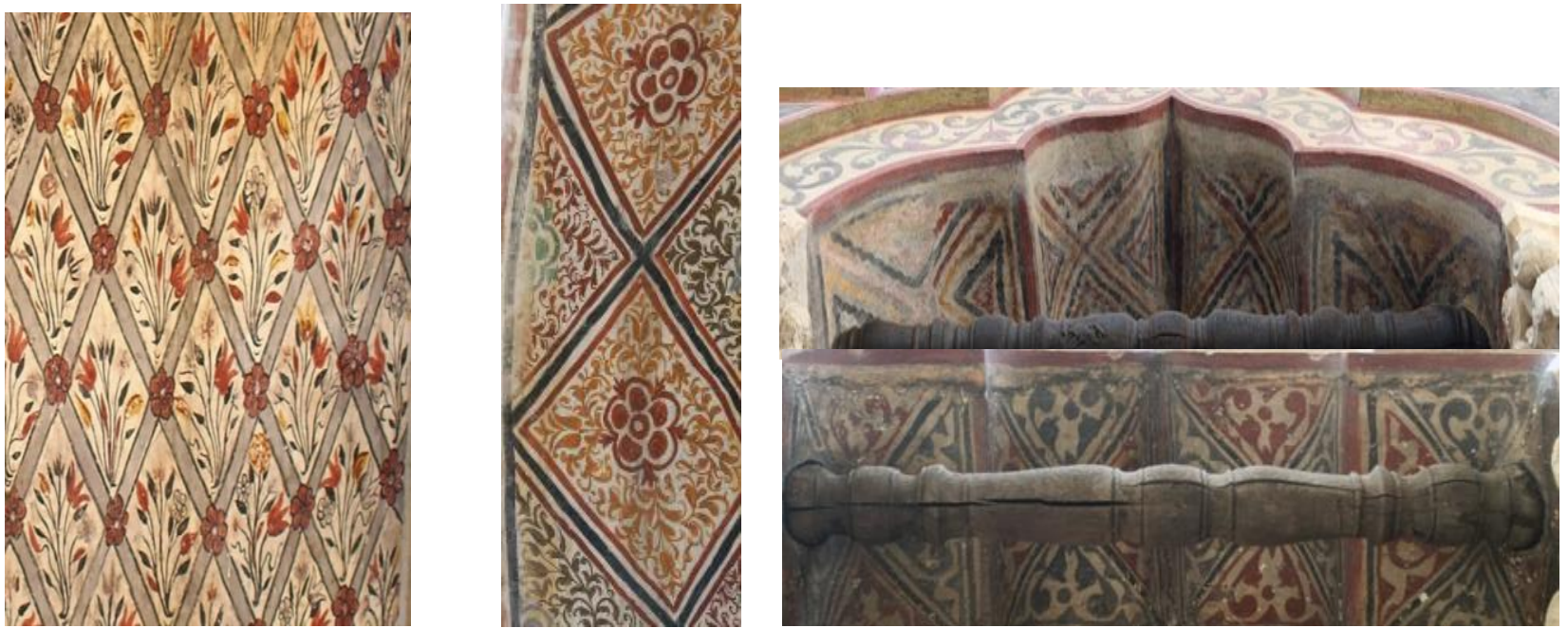

Fig.2. Brancovenian, vegetal and geometric ornaments

\subsection{The decoration of the elements encountered in paintings}

A new direction in the evolution of the ornament is its shift from merely decorating the architectural spaces to decorating the background of paintings. Brancovenian icons have a background filled with ornaments emphasized by vegetal, golden motifs. This decoration of the background increases the appereance quality of the artifacts changing the idea of empty space into that of richness and wealth. The shift of the ornament from merely giving the painting a finishing touch as it was in the case of the structures between the registers to the background of the scenes is done gradually enriching both the icons and the architectural groups. Right before the Brancovenian period, the decoration had begun to shift from the empty space to the background of the icon or scene (Nicolescu, Bucharest, 1976, p.30). But the evolution of the ornament in Brancovenian painting does not end here, the decorations being used also on the objects present in the second plan of the painting. Thus, painting becomes enriched with architectural elements like the citadels that are seen in the background of the paintings or thrones that become real masterpieces, suggesting the idea of luxury and richness (fig.4).

The thrones present in Brancovenian paintings are not just simple background items, they become true, decorative elements, decorated with geometric motifs made by delicate linings and floral motifs intertwined with ornamental stalks. Sometimes, on these thrones, we can see delicate animals and birds or even winged heads of angels borrowed from the Western culture. In no other part, does the ornament find its place in the painting like it does in this artistic period. The space of the elements that, until now, was filled only by light or colour, is receiving decorations, and as a consequence, they become intertwined.

Another feature of the Brancovenian painting is the application of the ornament over the characters' attire (fig.3). This feature finds its roots in Crete, where the attire of characters in the paintings were depicted with shadows and lights, and over it being able to see delicate, decorative motifs.

In Brancovenian painting, we can notice that the background is becoming intertwined with the model of the attire, this becoming a specific feature for it. Over the tones of shadow and light that shape the pleats of the attire, we can notice the exact representation of the Eastern arabesques. Whether in complete harmony with the attire or the shinning contrasts, these ornaments increase the importance of the moment and the value of the fabrics ( Nicolescu, 1976, p.30). 

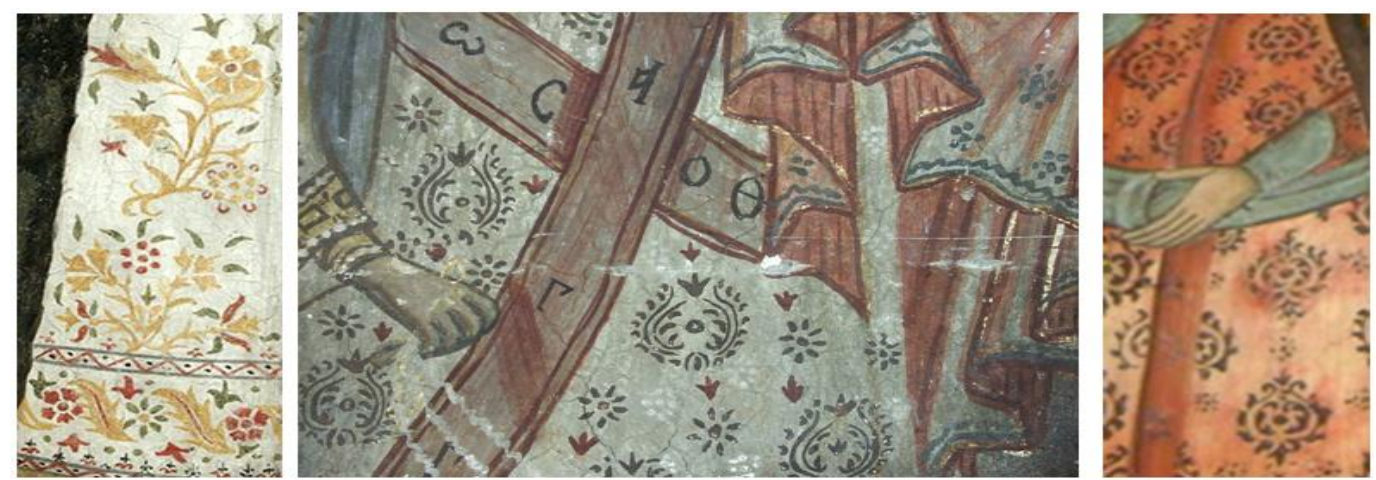

Fig.3. Ornaments on Brancovenian attire

Another motif that can be observed onto the characters' attire is the zoomorphus one (fig.6). In places we least expect, we observe elements from the animal world exquisitely executed. Never in the history of Byzantine painting, have these elements found their rightful place. Whether they are introduced in the background of the paintings or between the stalks of floral ornaments, the animals and the birds are nesting, finding their rightful place and giving a finishing touch to the richness of the ornaments. The importance of the zoomorphus motifs is underlined by their depiction on important characters' attire. Thus, on the knees of certain characters, we can observe delicate eagles, combining the symbol with the aesthetics of the picture.

In the Brancovenian period, we are witnessing the birth of the first antropomorphus motifs (http://episcopiaitaliei.it/) depicted at this level very well intertwined with the elements present in the painting.

In Brancovenian icon painting, the throne is seen as an element of props. On it, there are representations of angel faces, birds and animals that symbolize the absolute and undisputable reign of God All Mighty. They are not considered as elements, but this decoration is done at the same time as the shaping of shadows and lights.
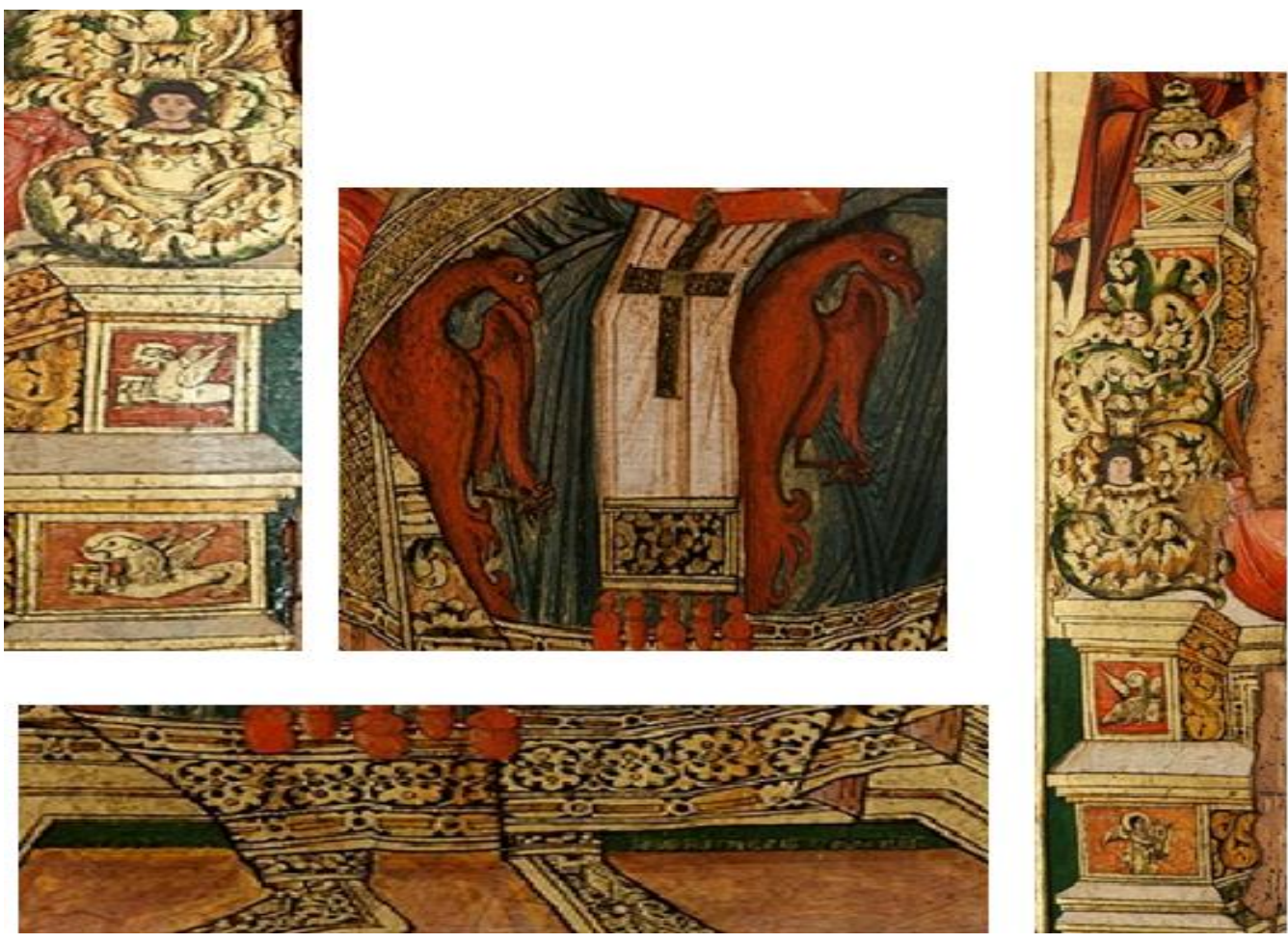

Fig.4. Ornaments positioned over the elements found in Brancovenian painting 


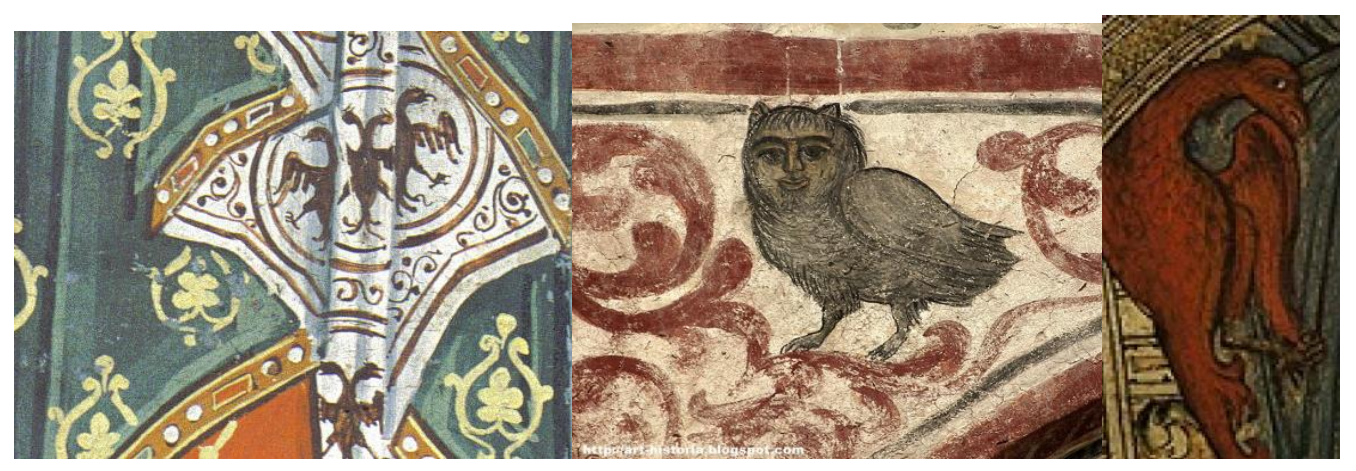

Fig. 5. Ornaments with zoomorphus motifs

\section{CONCLUSIONS}

The Brancovenian art represents the gradual shift of the painting of Muntenian painters from a balanced art to an accentuation of the Baroque spirit. It refers to an exaggeration in the use of ornaments and gold and a declining of forms and movement. We can observe important, Baroque influences, this leading to the predominance of vegetal motifs depicted in stalks (http://episcopia-italiei.it/) or intertwined in geometric shapes.

Thus, the attire of characters inspired by the Crete painting are enriched by ornaments with vegetal motifs, originating in the dust of the history, and adapted to the Western Baroque. By studying the plastic and stylistic analysis, we reach to the conclusion that the ornament has the sole purpose of decorating the background surfaces, phenomenon encountered in the tradition of Byzantine painting, and also, it is introduced in the painting, establishing an important relationship with it. Thus, Brancovenian painting manages to establish a synthesis between East and West, imposing itself as a personal style of the Romanian, Byzantine painting to universal art.

The ornament is endowed with multiple uses for the art; from filling in empty spaces to decorating the pictural space of objects and characters. Thus, the ornament becomes integrating part of each scene and character present in Brancovenian style.

Another feature of the Brancovenian ornament is the diversity of the used motifs, from flowers and plants to animals and birds that find their place in some of the most unexpected places, but also in the right places.All this features give the Brancovenian painting an unique aspect, imposing it as a personal style in the Romanian and universal Byzantine art.

After the end of the Brancovenian period, we can witness a more intense development of the spirit that lies deep within the heart of popular art, element that borrows icons with a new strength and a new graphics, but which also gives it a certain rigidity of forms and lines, a lesser focus on the richness and value of the colours and a simplicity in the designing and making of forms and structures(Efremov, 2003, p. 69).

\section{REFERENCE LIST}

Dobjanschi, Ana (1998), Georgescu.Maria, Editura Daim, Bucureşti.

Efremov, Alexandru, (2003)/coane româneşti, Editura Meridiane, Bucureşti.

Florea, Vasile, (2007), Istoria artei româneşti, Editura Litera Internaţional, Bucureşti- Chişinău, 2007.

Florea, Vasile, (1982), Rumänische Malerei, București 1982.

Nicolescu, Corina, (1976), Icoane vechi româneşti, Editura Meridiane Bucureşti.

Panaitescu, Alexandru,( 2008), Remember Mănăstirea Văcăreşti, Editura Simetria , Bucureşti.

Voinescu, Teodora, (1968), Pârvu Mutu Zugravu, Editura Meridiane,Bucureşti, 1968.

http://episcopia-italiei.it

https://ro.wikipedia.org/wiki/Stilul_brâncovenesc 